\title{
PERANCANGAN SISTEM HIDROLIK PADA UNIT MOBILE CORE SAMPLER
}

\author{
Fitria Adhi Geha Nusa ${ }^{1}$, Sugiyanto ${ }^{2}$
}

${ }^{1}$ Departemen Teknik Mesin/Sekolah Vokasi, Universitas Gadjah Mada, Indonesia Email: ${ }^{1}$ adhigeha@gmail.com, ${ }^{2}$ sugiyanto.ugm@gmail.com

\begin{abstract}
Sugarcane core sampler is a plantation equipment sector which collect sugar cane samples and determining of rendemen in sugarcane. Sugarcane core sampler is a new product made by PT. United Tractors Pandu Engineering to solve problem about determining of individual rendemen in sugarcane at sugar mill. In operation Sugarcane Core Sampler uses a hydraulic system as the prime mover, either to raise the platform, take samples of cane and push it out of the probe cylinder. In order for the hydraulic system to work optimally, it is necessary to design and calculate the specification of components to be used on tilting cylinders, ejector, hydraulic pump, and reservoir (hydraulic tank). It also conducted a discussion of the difference between the Core Sampler Sugarcane fixed and mobile models. From the calculation results obtained inside diameter tilting cylinder is $\emptyset 100 \mathrm{~mm}$ with rod cylinder $\emptyset 56 \mathrm{~mm}$, inside diameter of ejector cylinder is $\emptyset 32 \mathrm{~mm}$ with rod cylinder Ø1 8mm. At the biggest pump flow required is $51.81 \mathrm{lpm}$ and displacement $43 \mathrm{cc} / \mathrm{rev}$, from result of calculation hence specified pump which used is piston pump type with displacement $41 \mathrm{cc} / \mathrm{rev}$. For hydraulic tank capacity required on all hydraulic systems is 177 liters.
\end{abstract}

Keywords: sugarcane core sampler, core sampler, cylinder hydraulic, pump, reservoir.

\section{PENDAHULUAN}

Indonesia merupakan negara agraris dan sebagian besar penduduknya bermata pencaharian bidang pertanian. Salah satu subsektor pertanian tersebut adalah perkebunan. Secara umum bidang perkebunan mempunyai peranan yang sangat besar dalam penyedia lapangan pekerjaan, ketersediaan pangan, dan pertumbuhan ekonomi. Ditinjau dari segi peningkatan produksinya perkembangan perkebunan di Indonesia telah menunjukkan kemajuan yang sangat pesat, seperti komoditas sawit, karet, tebu, teh, kakao, kopi, maupun perkebunan lainnya. Berkembangnya komoditas perkebunan saat ini menyebabkan beberapa pabrik bersaing ketat untuk menghasilkan produk terbaiknya.

Salah satu komoditas yang berkembang saat ini, yaitu tanaman tebu. Tanaman tebu merupakan Famili Gramineae (keluarga rumput) dengan nama latin Saccharum officinarum yang sudah dibudidayakan sejak lama di daerah asalnya di Asia (Syakir dan Indrawanto, 2010). Menurut Ditjenbun (2011), luas areal tebu mencapai 418.260 ha tersebar di Jawa, Sumatra, dan Sulawesi. Dari luas areal tersebut terbanyak di Jawa Timur, yaitu mencapai 193.573 ha (54\%). Masa tanam optimal tebu ada dua pola, yaitu pola pertama pada awal musim kemarau sekitar Mei-Agustus, sedangkan pola kedua pada awal musim hujan September-November (Ditjenbun, 2011).

Masalah yang hingga kini sering dihadapi antara petani dengan perusahaan tebu, yaitu hasil kadar gula (rendemen) para petani yang belum akurat dan menunggu dalam waktu yang lama untuk mendapatkan hasilnya saat penjualan ke beberapa perusahaan. Saat ini, pabrik-pabrik gula di Indonesia mayoritas menentukan nilai kadar gula untuk para petani berdasarkan Nira Perahan Pertama (NPP). Metode tersebut memakan waktu yang sangat panjang dan membuat tebu menunggu lama untuk proses penggilingan. Salah satu teknologi untuk meningkatkan keakuratan rendemen dan dalam waktu yang singkat, yaitu menggunakan alat Sugarcane Core Sampler.

Sugarcane Core Sampler adalah alat yang digunakan untuk mengambil sampel tebu dari truck atau trailer dalam jumlah tertentu yang kemudian dianalisa untuk mengetahui kandungan rendemennya. Selain mampu memberikan akurasi data yang tinggi, hasil analisa alat Sugarcane Core Sampler juga mampu dijadikan sebagai dasar screening kualitas tebu secara cepat bagi pabrik sehingga kemungkinan untuk menyeragamkan kualitas tebu yang akan digiling di pabrik dapat dilakukan (Saputro, 2013). Terdapat dua tipe Core Sampler di dunia, yaitu tipe horizontal dan tipe vertikal.

PT. United Tractors Pandu Engineering (PATRIA) merupakan salah satu perusahaan multinasional yang bergerak di bidang industri alat berat. Pada sektor forestry \& agro, selain memproduksi Composting Tower, saat ini sedang dikembangkan produk baru yaitu Sugarcane Core Sampler dengan bentuk mobile. Bentuk mobile ini diklaim merupakan yang pertama dalam dunia indutri gula. Pada saat ini Sugarcane Core Sampler yang dikembangkan masih dalam bentuk fix sehingga para petani tebu harus ke pabrik dan menunggu lama untuk mengetahui kandungan rendemennya.

Sugarcane Core Sampler model mobile yang bisa dipindahkan ini dikembangkan dengan menggunakan sistem hidrolik sebagai penggerak utama, baik untuk menurunkan unit dari truck maupun untuk menaikkannya kembali. Sistem 
hidrolik pada unit Sugarcane Core Sampler ini terdiri dari tiga komponen utama, yaitu power pack, control element, dan actuator. Agar unit ini bisa bekerja dengan baik, maka pada sistem hidrolik perlu dilakukan perancangan dan perhitungan untuk pemilihan komponen yang akan digunakan, terutama pada cylinder hydraulic, hydraulic pump, dan reservoir (tangki hidrolik).

\section{BAHAN DAN METODE PENELITIAN}

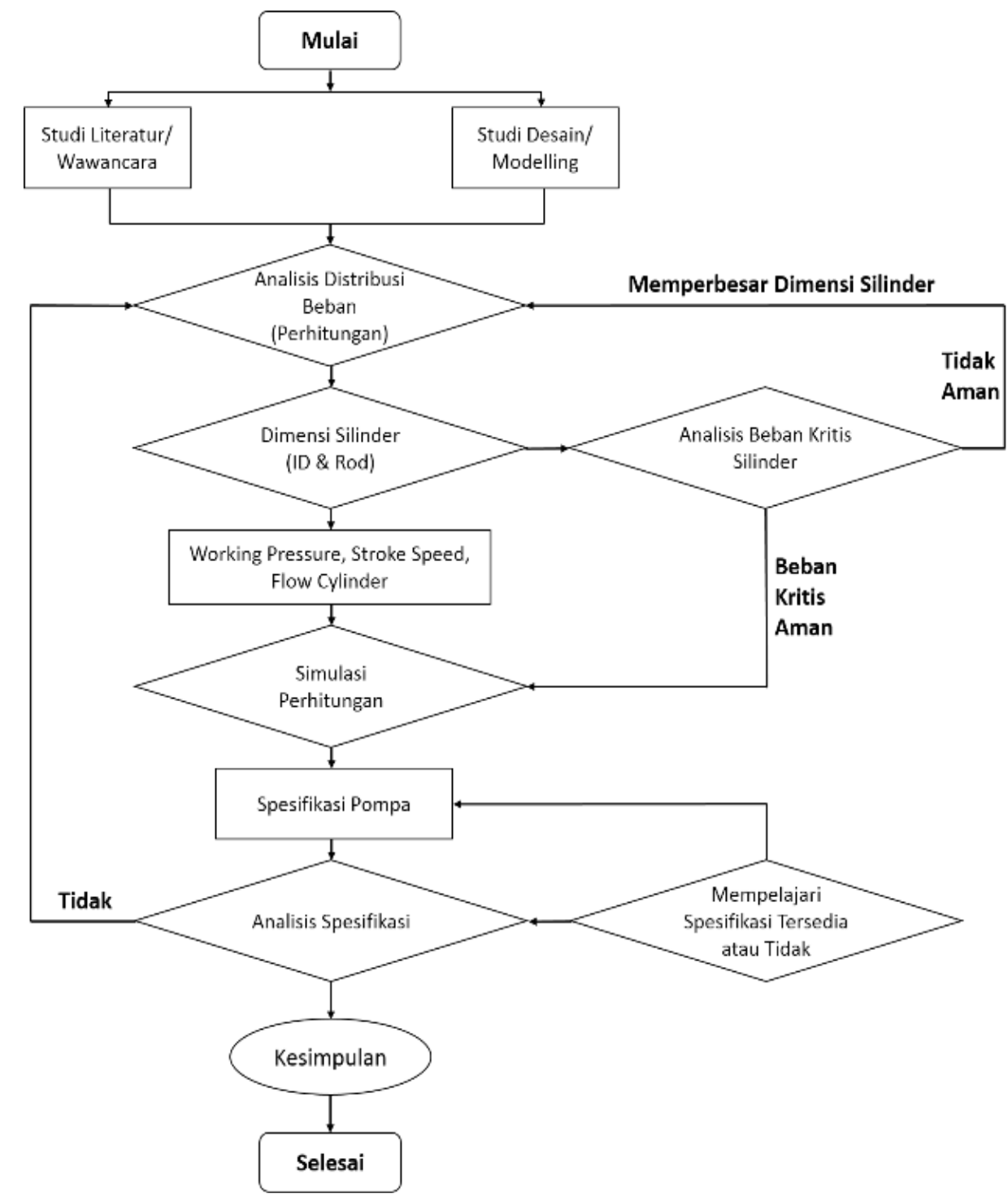

Gambar 1. Diagram alur perancangan

Dalam proses perancangan perlu dilakukan sistematika alur yang jelas dan tepat untuk mendapatkan hasil yang maksimal. Proses tersebut memerlukan alur perhitungan sehingga dapat mempermudah dalam merancang dan menentukan spesifikasi komponen yang dihitung. Flowchart perhitungan silinder, pompa, dan tangki hidrolik dapat dilihat pada Gambar 1. Proses perancangan terdiri dari beberapa tahapan: 
1. Melakukan metode penelitian dengan studi literatur dan studi desain/modelling;

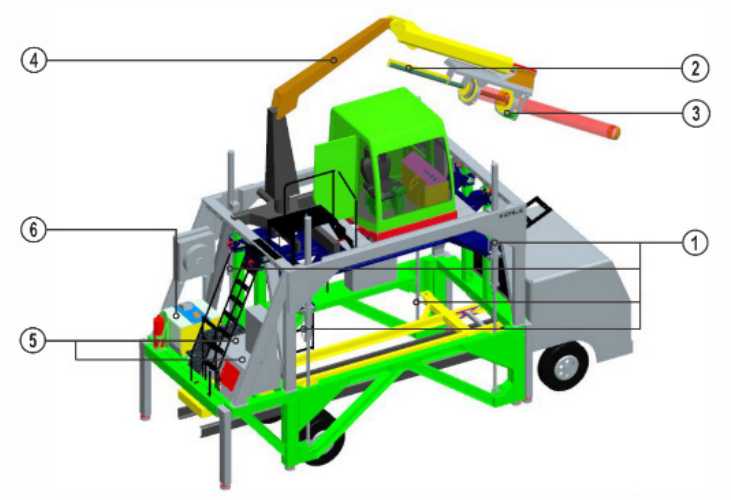

Gambar 2. Bagian-bagian sistem hidrolik unit Sugarcane Core Sampler

Keterangan:

1) Silinder tilting;

2) Silinder ejector;

3) Motor hidrolik;

4) Hyva crane (swing, boom, arm, telescopic);

5) Pompa 1 dan Pompa 2;

6) Tangki Hidrolik (reservoir).

2. Analisa distribusi beban pada masing-masing silinder dan menghitung dimensi silinder;

3. Analisa beban kritis (working pressure, stroke speed, dan flow cylinder);

4. Analisa untuk menentukan spesifikasi pompa yang sesuai dengan kebutuhan;

5. Simulasi perhitungan dari perancangan yang telah dilakukan;

6. Analisa perbedaan Sugarcane Core Sampler model fix dan mobile.

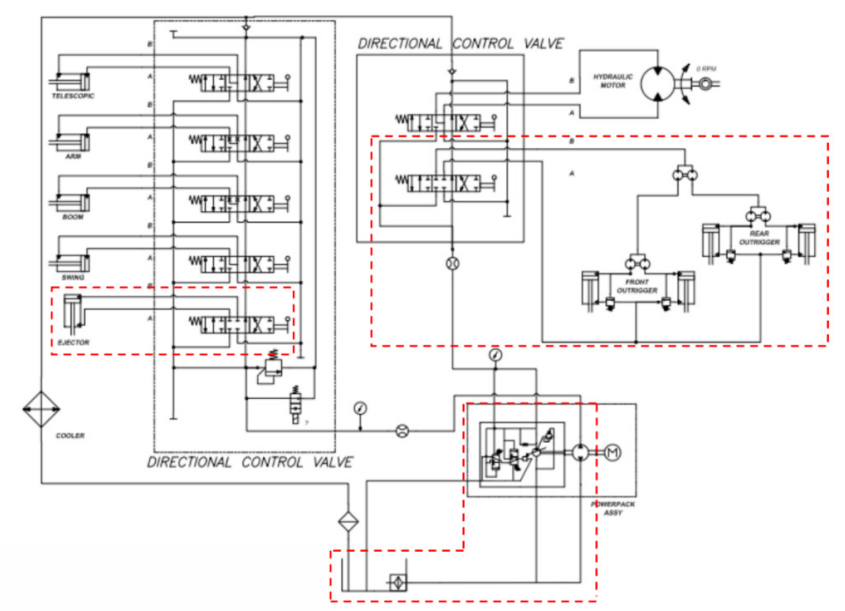

Gambar 3. Skema hidrolik Sugarcane Core Sampler (Wijaya, 2016)

Gambar 3 adalah skema sistem hidrolik pada unit Sugarcane Core Sampler. Sistem hidrolik terdiri dari tiga bagian komponen utama, yaitu power pack (unit tenaga), control element (unit pengatur), dan actuator (unit penggerak). Bagian power-input terdiri dari penggerak utama (prime over) dan pompa. Pada unit Sugarcane Core Sampler penggerak utamanya adalah motor elektrik. Kemudian energi mekanik dari penggerak diubah menjadi energi kinetik dan energi tekanan pada fluida. Bagian kontrol terdiri dari rangkaian katup (valve) yang dikontrol melalui sistem tekanan, laju aliran, arah aliran 
fluida, actuator, dan lain-lain. Bagian power-output merupakan bagian yang mengubah energi kinetik dan energi tekanan fluida ke energi mekanik.

Tabel 1. Komponen hidrolik Sugarcane Core Sampler

\begin{tabular}{|c|c|c|c|}
\hline $\begin{array}{l}\text { Komponen } \\
\text { utama }\end{array}$ & Bagian & Fungsi & Gambar \\
\hline \multirow{3}{*}{ Power pack } & Pompa hidrolik & $\begin{array}{l}\text { Mengubah energi mekanik menjadi tenaga } \\
\text { tekan hidrolik dengan cara mendorong } \\
\text { fluida ke sistem }\end{array}$ & \\
\hline & Motor listrik/ prime mover & $\begin{array}{l}\text { Sebagai penggerak utama yang } \\
\text { memberikan energi kinetik pada pompa }\end{array}$ & \\
\hline & Tangki hidrolik/ reservoir & Sebagai penampung fluida hidrolik sistem & \\
\hline
\end{tabular}
Untuk menjaga fluida hidrolik tetap bersih
dalam sistem hidrolik

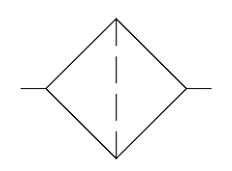

\section{Control \\ 4/3 Way valve/ main}

elements control valve
Katup kontrol 4/3 dengan actuation on/off solenoid, untuk mengatur stroke up/down silinder aktuator
Solenoid valve normally closed
Untuk mengontrol fluida yang bertekanan ke aktuator

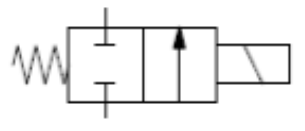




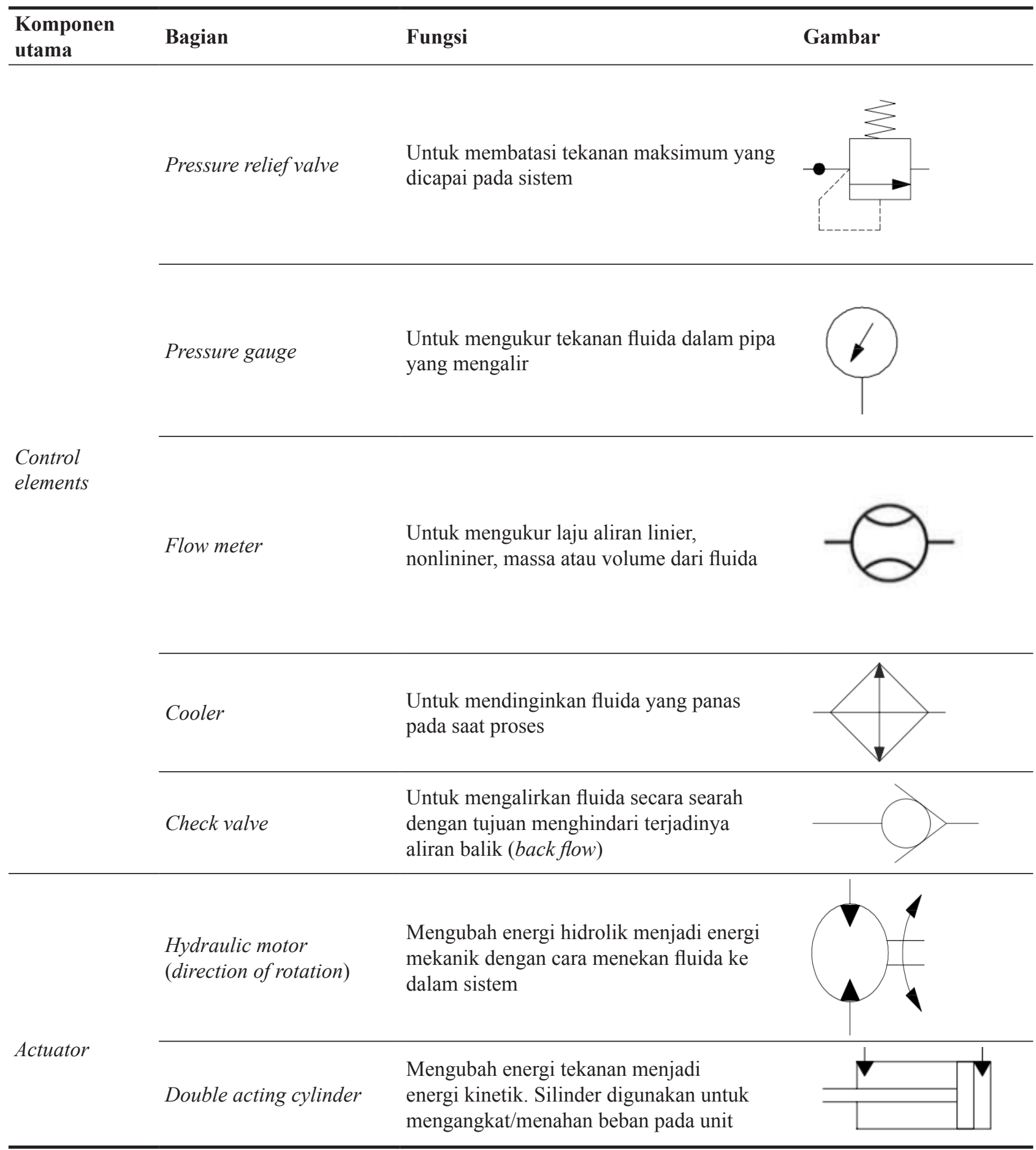


3. HASIL DAN PEMBAHASAN

3.1 Perhitungan Gaya Silinder Tilting

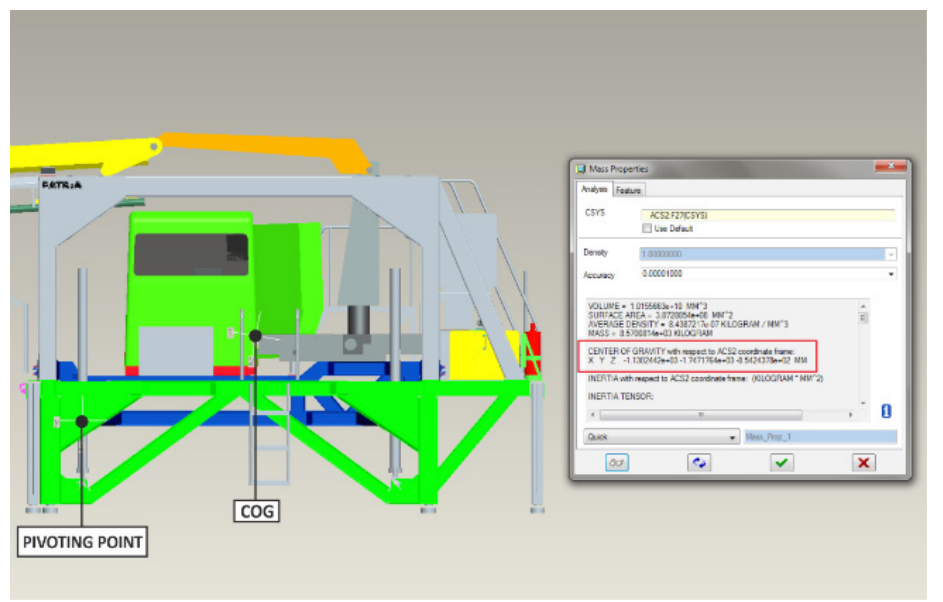

Gambar 4. Hasil analisa COG

Dari hasil analisa didapatkan massa total sebesar 4,531 x $10^{4} \mathrm{~kg}$ dengan koordinat COG dari pivoting point pin adalah $\mathrm{x}=1,130 \times 10^{4} \mathrm{~mm} ; \mathrm{y}=1,747 \times 10^{4} \mathrm{~mm}$; dan $\mathrm{z}=8,54 \times 10^{2} \mathrm{~mm}$.

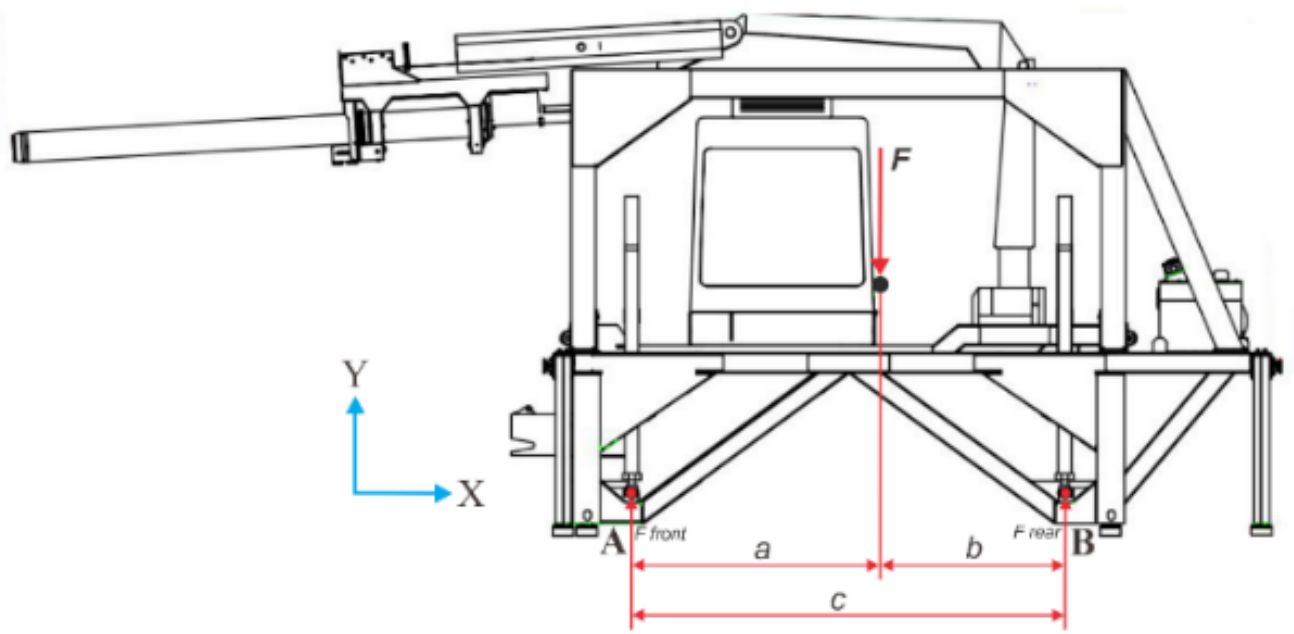

Gambar 5. Skema distribusi beban silinder tilting

Langkah selanjutnya adalah mengimplementasikan hasil analisa tersebut pada perhitungan distribusi beban. Digunakan konsep kesetimbangan untuk menghitung besarnya gaya diterima oleh silinder tilting sehingga dapat menentukan besar gaya yang dibutuhkan oleh silinder tilting (F). Skema perhitungan distribusi beban dapat dilihat pada Gambar 5 diatas. Dari hasil perhitungan, diperoleh $\mathrm{a}=1,747 \mathrm{~m} ; \mathrm{b}=1,403 \mathrm{~m} ; \mathrm{c}=3,150 \mathrm{~m}$; dan massa total $=4,889 \times 10^{4} \mathrm{~kg}$. Jadi, nilai beban total $\left(W_{\text {skeleton deck }}\right)$ adalah sebesar $48890 \mathrm{~N}$. Resultan gaya masing-masing tumpuan $\left(\mathrm{F}_{\text {front }} \& \mathrm{~F}_{\text {rear }}\right)$ adalah $F_{\text {rear }}=27,1 \mathrm{kN}(\uparrow)$ dan $F_{\text {front }}=21,8 \mathrm{kN}(\uparrow)$. Sementara itu, panjang maksimum dari silinder tilting adalah $3858 \mathrm{~mm}$ dan panjang minimum adalah $2208 \mathrm{~mm}$ sehingga panjang langkah (stroke) adalah $1650 \mathrm{~mm}$. Penentuan inside diameter dilakukan dengan menyesuaikan gaya yang dibutuhkan pada silinder tilting dari perhitungan distribusi beban gaya yaitu sebesar 27.114,5 N pada masingmasing silinder (Tabel 2). 
Tabel 2. Tabel Theoritical Output Cylinder (ISO Standard Hydraulic Cylinder)

\begin{tabular}{|c|c|c|c|c|c|c|c|}
\hline \multirow{2}{*}{$\begin{array}{l}\text { Bore size } \\
(\mathrm{mm})\end{array}$} & \multirow{2}{*}{$\begin{array}{l}\text { Rod size } \\
(\mathrm{mm})\end{array}$} & \multirow{2}{*}{$\begin{array}{l}\text { Operation } \\
\text { direction }\end{array}$} & \multirow{2}{*}{$\begin{array}{l}\text { Piston area } \\
\left(\mathrm{mm}^{2}\right)\end{array}$} & \multicolumn{4}{|c|}{ Operating pressure (MPa) } \\
\hline & & & & 3,5 & 7 & 10 & 16 \\
\hline \multirow{2}{*}{32} & \multirow{2}{*}{18} & OUT & 804 & 2814 & 5628 & 8040 & 12864 \\
\hline & & IN & 549 & 1922 & 3843 & 5490 & 8784 \\
\hline \multirow{2}{*}{40} & \multirow{2}{*}{22} & OUT & 1256 & 4396 & 8792 & 12560 & 20096 \\
\hline & & IN & 876 & 3066 & 6132 & 8760 & 14016 \\
\hline \multirow{2}{*}{50} & \multirow{2}{*}{28} & OUT & 1963 & 6871 & 13741 & 19630 & 31408 \\
\hline & & IN & 1347 & 4715 & 9429 & 13470 & 21552 \\
\hline \multirow{2}{*}{63} & \multirow{2}{*}{36} & OUT & 3117 & 10910 & 21819 & 31170 & 49872 \\
\hline & & IN & 2099 & 7346 & 14693 & 20990 & 33584 \\
\hline \multirow{2}{*}{80} & \multirow{2}{*}{45} & OUT & 5026 & 17591 & 35182 & 50260 & 80416 \\
\hline & & IN & 3436 & 12026 & 24052 & 34360 & 54976 \\
\hline \multirow{2}{*}{100} & \multirow{2}{*}{56} & OUT & 7853 & 27486 & 54971 & 78530 & 125648 \\
\hline & & IN & 5390 & 18865 & 37730 & 53900 & 86240 \\
\hline
\end{tabular}

Keterangan:

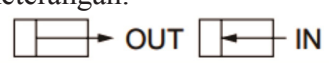

Dari Tabel 2 didapatkan inside diameter yang digunakan adalah Ø100 mm dengan besar diameter rod silinder Ø56 $\mathrm{mm}$. Setelah itu, dilakukan analisa pada rod silinder untuk mengetahui apakah kondisinya aman dari buckling. Berdasarkan hasil perhitungannya $F_{\text {tilting }}<\mathrm{P}_{\mathrm{cr}}$, maka rod silinder tilting aman dengan safety factor 4,5 kali dari $F$ sehingga didapatkan working pressure $(p)$ yang dibutuhkan di masing-masing silinder sebesar 8,6 bar. Berdasarkan waktu tempuh yang telah disepakati dengan customer, didapatkan kecepatan silinder $0,028 \mathrm{~m} / \mathrm{s}$ dengan flow $51,81 \mathrm{lpm}$.

\subsection{Perhitungan Gaya Silinder Ejector}

Silinder ejector berfungsi untuk mendorong sampel tebu untuk keluar dari dalam lubang silinder. Silinder ini mendorong sampel tebu pada sudut kemiringan antara $45^{\circ}$ sampai $60^{\circ}$ dan ke arah bawah. Beban yang digerakkan atau didorong silinder ejector hanya beban sampel tebu yang bobotnya 17,66 kg. Bentuk silinder pada probe assy ditunjukkan seperti pada Gambar 6.

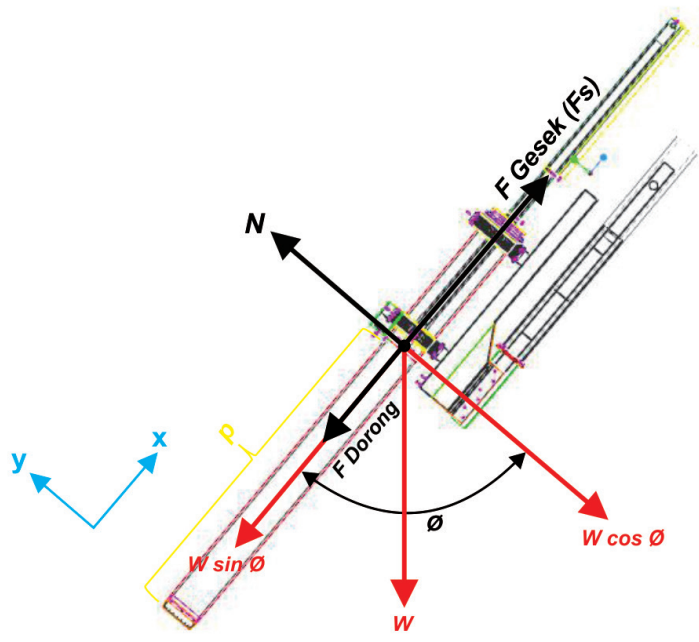

Gambar 6. Skema distribusi beban silinder ejector

Pada mekanisme silinder ejector bekerja, pada ujung silinder ejector mendorong sampel tebu untuk keluar dari dalam silinder probe. Pada saat mendorong, akan timbul gesekan antara tebu dan silinder probe (steel-wood) dengan massa jenis tebu $=352,4 \mathrm{~kg} / \mathrm{m}^{3}$; Inside Diameter $(\mathrm{ID})$ silinder probe $=193,8 \mathrm{~mm}$; kedalaman penetrasi $(p)=1,7 \mathrm{~m}$; koefisien gesek $(\mu \mathrm{s})=0,5$; dan sudut yang dibentuk probe $(\theta)=45^{\circ}$. Dengan luas penampang silinder probe sebesar $29.483 \mathrm{~mm}^{2} \mathrm{dan}$ volume 
silinder probe sebesar $0,05 \mathrm{~m}^{3}$ dengan volume silinder probe jika diisi dengan tebu adalah 17,66 $\mathrm{kg}$ sehingga didapatkan gaya normal $(\mathrm{N})=0,125 \mathrm{Kn}$, gaya gesek $=0,06 \mathrm{Kn}$, dan nilai $F=62,44 \mathrm{~N}(62,44 \mathrm{kN})$.

Panjang maksimum dari silinder ejector $4282 \mathrm{~mm}$ dan panjang minimumnya $2282 \mathrm{~mm}$ sehingga panjang langkah (stroke) adalah $2000 \mathrm{~mm}$. Penentuan Inside Diameter dilakukan dengan menyesuaikan gaya yang dibutuhkan pada silinder ejector dari perhitungan distribusi beban gaya dengan safety factor 4 kali, nilai 62,44 $\mathrm{N}$ dikalikan dengan nilai implisit 5 adalah sebesar 312,24 N. Karena beban gaya yang kecil, maka penentuan inside diameter dilakukan dengan melihat ISO Standart Hydraulic pada Tabel 1. Didapatkan inside diameter terkecil adalah Ø32 $\mathrm{mm}$ dengan besar diameter rod nya adalah $\varnothing 18 \mathrm{~mm}$. Selanjutnya, dilakukan perhitungan beban kritis rod pada silinder ejector untuk menghindari terjadinya buckling. Berdasarkan perhitungan beban kritis rod $F_{\text {tilting }}<\mathrm{P}_{\mathrm{cr}}$, maka silinder rod ejector aman dengan safety factor 6,7 kali. Dari analisa diketahui working pressure silinder ejector yang dibutuhkan adalah sebesar 3,11 bar sehingga didapatkan kecepatan silinder $0,10 \mathrm{~m} / \mathrm{s}$ dan flow silinder $4,82 \mathrm{lpm}$.

\subsection{Menentukan Pompa Hidrolik}

Penentuan spec pompa dapat dilakukan dengan mengetahui displacement yang dibutuhkan untuk menunjang performa silinder yang digunakan. Pada unit Sugarcane Core Sampler pompa yang digunakan adalah sebanyak dua buah pompa. Pompa pertama untuk menunjang performa silinder tilting, ejector dan HYVA, sedangkan silinder kedua untuk menunjang motor hidrolik. Berdasarkan data dari HYVA HB60 Technical Sheet didapatkan flow HYVA crane sebesar 20 lpm.

- Flow Cylinder Tilting: 51,81 1pm;

- Flow Cylinder Ejector: 7,54 lpm;

- Flow Cylinder HYVA: 20 lpm.

Berdasarkan data diatas, maka dapat diketahui hasil flow silinder terbesar adalah 51,81 lpm dan diketahui pula putaran engine pada posisi idle adalah $1500 \mathrm{rpm}$. Berdasarkan data pengujian diketahui nilai pressure stand by adalah 80 bar, sedangkan pressure working adalah 160 bar sehingga nilai $\Delta \mathrm{p}$ dapat ditentukan sebesar 80 bar. Dari hasil perhitungan didapatkan Displacement $(\mathrm{D})=43 \mathrm{cc} / \mathrm{rev}$, Torque $=61 \mathrm{Nm}$, dan Power $(\mathrm{P})=12 \mathrm{HP}$.

Berdasarkan besaran displacement, torque, dan power perhitungan pompa, ditentukan pompa yang akan digunakan adalah tipe Piston Pump. Selanjutnya, pemilihan spec pompa piston pump dilakukan berdasarkan nilai displacement terdekat. Piston pump biasa dipakai untuk kecepatan dan tekanan yang tinggi di mana piston pump lebih komplek dan didesain untuk tipe fixed (tetap) atau variable (bervariasi) displacementnya. Spesifikasi yang dipilih adalah yang mendekati dari nilai perhitungan pompa diatas, yaitu dengan nilai displacement $41 \mathrm{cc} / \mathrm{rev}$.

\subsection{Perhitungan Kapasitas Tangki Hidrolik}

Penentuan kapasitas tangki hidrolik yang dibutuhkan pada unit Sugarcane Core Sampler ini dilakukan dengan cara menghitung volume dari silinder tilting, ejector, HYVA, dan motor hidrolik. Sistem hidrolik unit Sugarcane Core Sampler menggunakan sistem oil cooling seperti radiator. Perhitungan voume tangki hidrolik dilakukan dengan cara mengalikan total volume dengan faktor static cooling untuk safety factor dalam proses kerja dan untuk membantu siklus pendinginan dengan besaran implisit yaitu sebesar 2. Sesuai data katalog HYVA diketahui bahwa volume dari HYVA adalah 35 liter. Berdasarkan perhitungan, kapasitas fluida yang dibutuhkan adalah sebesar 177 liter.

\subsection{Sugarcane Core Sampler Model Fix dan Mobile}

Pada dasarnya, sistem core sampling bukan hal yang baru dalam industri gula dunia. Sistem ini pertama kali digunakan sebagai evaluasi kualitas tebu dan penghitungan bagi hasil petani di Lousiana pada tahun 1978. Beberapa tahun kemudian setelah sistem ini terbukti berhasil, maka negara-negara lainpun mulai menggunakan sistem ini untuk menggantikan sistem pengambilan sampel yang lama. Selain mampu memberikan akurasi data yang tinggi, sistem core sampling terbukti juga mampu menjadi dasar screening kualitas tebu secara cepat bagi pabrik sehingga kemungkinan untuk menyeragamkan tebu yang akan digiling di pabrik dapat dilakukan (Saputro, 2015). 


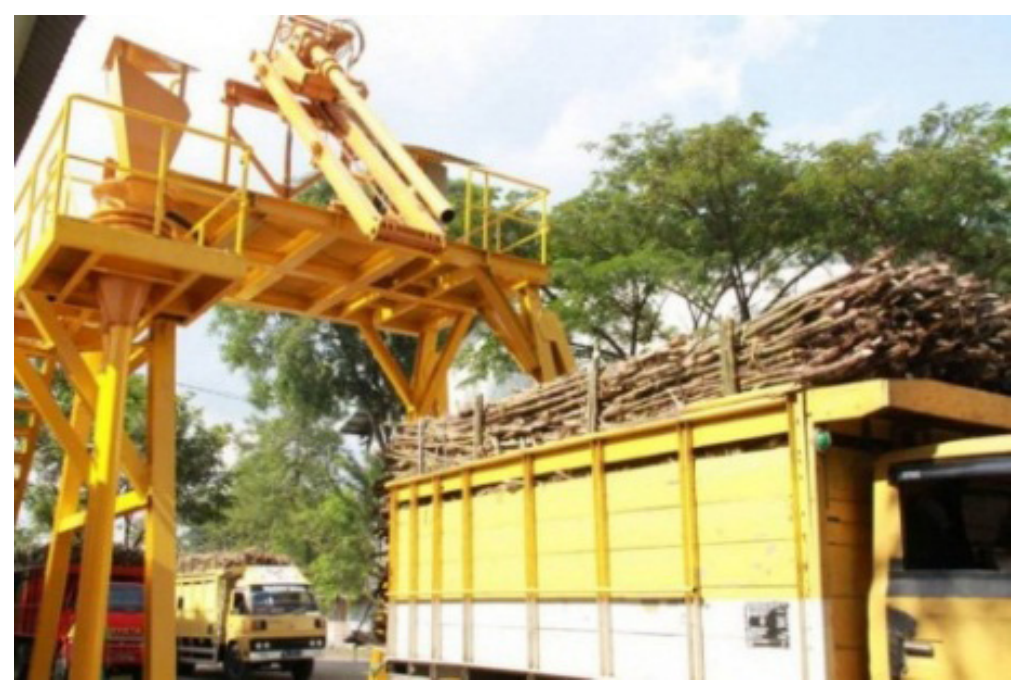

Gambar 7. Core Sampler model fix

Gambar 9 adalah model core sampler dengan bentuk fix. Pada model fix, penggunaan alat core sampler bersifat tetap sehingga untuk mengetahui nilai kandungan rendemen dalam gula harus ke pabrik gula. Selama ini para petani tebu mengirim hasil panen tebu mereka ke pabrik-pabrik gula terdekat untuk menjual dan mengetahui nilai kandungan rendemen dalam tebu. Penggunaan core sampler model fix membutuhkan tempat yang luas sehingga biasanya model fix seperti ini terdapat di pabrik gula dan sekaligus tempat penggilingan tebu.

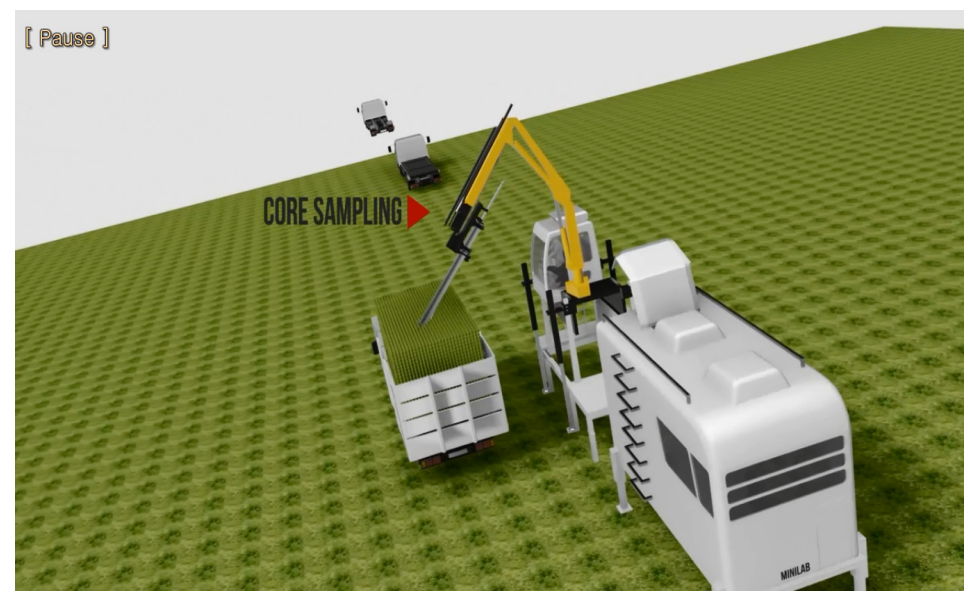

Gambar 8. Core Sampler model mobile

Pada Gambar 10 dapat dilihat model core sampler berbentuk mobile yang merupakan konsep desain pertama kali di dunia industri gula. Model mobile core sampler merupakan perkembangan dari bentuk fix yang sudah ada sebelumnya. Keuntungan dengan adanya mobile core sampler dibandingkan dengan model sebelumnya adalah mudah dipindahkan, memiliki durability yang baik, tidak memerlukan ruang yang luas, memiliki akurasi yang tinggi, dan siklusnya singkat antara 4-5 menit setiap satu sampel (mulai bor sampai data analisa). Selain itu, dengan mobile core sampler pabrik-pabrik gula dapat melakukan pengecekan secara langsung di tempat penanaman tebu sehingga para petani bisa mengetahui secara langsung nilai kandungan rendemen. Dengan adanya transparansi nilai rendemen antara pabrik gula dan petani tebu bisa meningkatkan kualitas tebu di Indonesia dan mendongkrak rendemen tebu yang ada sehingga target rendemen tebu sebesar $10 \%$ dapat terealisasi.

\section{KESIMPULAN}

Setelah melakukan perhitungan dan analisa pada bab sebelumnya, maka dapat ditarik beberapa kesimpulan. Dari perhitungan silinder tilting dan ejector yang sudah dilakukan didapatkan hasil bahwa untuk silinder tilting diketahui memiliki Inside Diameter (ID) $100 \mathrm{~mm}$, Rod $56 \mathrm{~mm}$, Stroke $1650 \mathrm{~mm}$, dan tekanan kerja minimal yang dibutuhkan silinder adalah 
8,6 bar pada masing-masing silinder. Sementara itu, untuk silinder ejector diketahui memiliki Inside Diameter (ID)) 32 $\mathrm{mm}$, rod $18 \mathrm{~mm}$, stroke $2000 \mathrm{~mm}$, dan tekanan kerja minimal yang dibutuhkan silinder adalah 3,1 bar. Komponen pompa yang akan digunakan adalah piston pump dengan besaran displacement $41 \mathrm{cc} / \mathrm{rev}$ dan kapasitas tangki yang dibutuhkan adalah sebesar 177 liter.

\section{DAFTAR PUSTAKA}

Anonim. (2002). Pengetahuan Hidrolik. Bandung: Laboratorium Perancangan Mesin Institut Teknologi Bandung.

Hakim, Ridwan Isnan. 2014. Perancangan Silinder Pompa dan Tangki Hidrolik pada Unit Passenger Stair PT United Tractors Pandu Engineering. Tugas Akhir. Departemen Teknik Mesin UGM. Yogyakarta.

Ismail. (2010). Basic Hydraulic System Material. Bekasi: PT United Tractors Pandu Engineering.

Partowinoto, S. (1996). Core Sampler merupakan Salah Satu Sistem Alternatif yang Mampu Menghargai Prestasi Individu Pembudidaya Tebu. Berita P3GI 17.

Purna Irawan, Agustinus. (2007). Mekanika Teknik (Statika Struktur). Jakarta: Unversitas Tarumanegara.

Pusat Data dan Sistem Informasi Pertanian. (2014). Outlook Komoditi Tebu. Jakarta: Kementerian Pertanian.

Saputro, Rifai Rahman. Penerapan Sistem Core Sampling Di Pabrik Gula. http://sugar.lpp.ac.id/penerapan-sistem-coresampling-di-pabrik-gula/ Akses 12.05.17

Setyo Yuwono, Sudarminto. Tanaman Tebu (Saccarum officinaru). http://darsatop.lecture.ub.ac.id/2015/10/tanaman-tebusaccarum-officinaru/ Akses 12.05.17 